\title{
PENGARUH MODEL PEMBELAJARAN KOOPERATIF TIPE THINK PAIR SHARE TERHADAP HASIL BELAJAR MATEMATIKA SISWA KELAS VIII SMPN 17 KOTA BENGKULU
}

\author{
Cindy Samya Putri ${ }^{1}$, Effie Efrida Muchlis ${ }^{2}$, Rusdi $^{3}$ \\ ${ }^{1,2,3}$ Universitas Bengkulu, FKIP, Program Studi Pendidikan Matematika

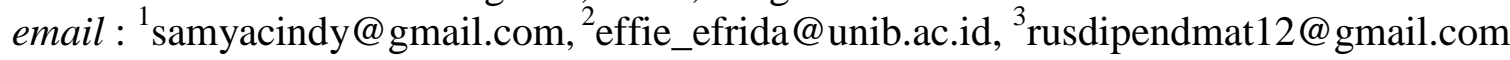

\begin{abstract}
Abstrak
Penelitian ini bertujuan untuk mengetahui pengaruh model pembelajaran Think Pair Share terhadap hasil belajar matematika siswa kelas VIII SMPN 17 Kota Bengkulu. Jenis penelitian yang dilakukan adalah penelitian eksperimen semu dengan desain penelitian The Nonequivalent Pretest-Posttest Control Design. Populasi siswa dalam penelitian ini adalah siswa kelas VIII SMPN 17 Kota Bengkulu. Pemilihan sampel dengan teknik Purposive Sampling didapat siswa Kelas VIIID sebagai kelas eksperimen dan Kelas VIIIE kelas kontrol. Analisis data dilakukan dengan uji-t paired, uji-t independent, dan perhitungan nilai N-Gain. Pada uji-t paired untuk hasil pretes dan postes kelas eksperimen didapat angka sig.(2-tailed) $=0,000<\operatorname{taraf}$ signifikan $(\alpha=0,05)$ yang menunjukkan bahwa terdapat perbedaan yang signifikan antara hasil belajar siswa sebelum dan sesudah model pembelajaran Think Pair Share diterapkan. Sedangkan pada uji-t independen hasil postes kelas sampel dengan taraf signifikan $(\alpha=0,05)$ didapat angka sig.(2-tailed) $=0,047<\operatorname{taraf}$ signifikan $(\alpha=$ $0,05)$ dan $t_{\text {hitung }}=2,041>t_{\text {tabel }}=2,010635$ yang menunjukkan bahwa terdapat perbedaan antara hasil belajar matematika antara siswa dengan pembelajaran Think Pair Share dan ekspositori. Pada perhitungan nilai $\mathrm{N}$-Gain didapat rata-rata angka $\mathrm{N}$-Gain pada kelas eksperimen yakni 0,47(sedang) dan kelas kontrol 0,34 (sedang), didapati bahwa angka kenaikan hasil belajar pada kelas eksperimen lebih tinggi daripada kelas kontrol. Hasil penelitian menunjukkan bahwa terdapat pengaruh model pembelajaran Think Pair Share terhadap hasil belajar matematika siswa Kelas VIII SMPN 17 Kota Bengkulu.
\end{abstract}

Kata kunci : hasil belajar, model pembelajaran Think Pair Share (TPS), pembelajaran matematika

\begin{abstract}
This study aims to determine the effect of Think Pair Share learning model on mathematics learning outcomes of students of class VIII SMPN 17 Kota Bengkulu. The type of research conducted is a quasiexperimental research with the design of The Nonequivalent Pretest-Posttest Control Design. The population of the students in this study was the eighth grade students of SMPN 17 Kota Bengkulu. The sample selection using Purposive Sampling technique was obtained by the students of Class VIIID as experimental class and Class VIIIE of control class. Data analysis was carried out by paired t-test, independent $t$-test, and calculation of $N$-Gain values. In the paired t test for the results of the pretest and postes of the experimental class, the number of sig (2-tailed) $=0,000<$ significance $(\alpha=0,05)$ indicates that there is a significant difference between the students' learning outcomes before and after the Think learning model Pair Share applied. Whereas in the independent t-test the result of postes of sample class with significant level $(\alpha=0,05)$ got sig rate $(2$-tailed $)=0,047<$ significant level $(\alpha=$ $0,05)$ and $t$ count $=2,041>t$ table $=2,010635$ which shows that there is a difference between mathematics learning outcomes between students with Think Pair Share and expository learning. In the calculation of $\mathrm{N}$-Gain values, the average number of $\mathrm{N}$-Gains in the experimental class is 0.47 (medium) and control class is 0.34 (medium), it is found that the increase of learning result in the experimental class is higher than the control class. The results showed that there is influence of learning model of Think Pair Share on mathematics learning result of students of Class VIII SMPN 17 Kota Bengkulu.
\end{abstract}

Cindy, Effie, Rusdi

Pengaruh Model Pembelajaran Kooperatif Tipe Think Pair Share Terhadap Hasil Belajar Matematika Siswa Kelas VIII SMPN 17 Kota Bengkulu 
Keywords : learning outcomes, Think Pair Share (TPS) learning models, mathematics learning

\section{PENDAHULUAN}

Pendidikan di Indonesia berkembang dari waktu ke waktu, segala perangkat pendidikan yang ada disesuaikan seiring dengan perkembangan zaman. Posisi guru sebagai pentransfer ilmu pengetahuan berperan sangat penting. Guru dituntut untuk dapat menyesuaikan diri dengan segala perkembangan pendidikan yang ada, mulai dari kurikulum yang berubah sampai dengan perubahan sistem pendidikan. Berbagai metode khusus pun terus dikembangkan oleh guru agar materi yang disampaikan dapat menuai hasil maksimal. Selain itu, peran pemerintah juga ditunjukkan dengan penerapan dan perbaikan kurikulum.

Dalam menunjang perkembangan pendidikan, guru hendaknya memfokuskan pada setiap mata pelajaran salah satunya matematika. Matematika adalah pelajaran yang sangat penting di semua jenjang pendidikan. National Research Council (1989:1) menyatakan "Mathematic is the key opportunity", hal ini menunjukkan posisi matematika benar-benar dikagumi dunia karena mampu menarik segala bidang ilmu dalam penerapannya. Mengingat pentingnya matematika ini, pembelajaran matematika harus dilakukan dengan tepat. Seorang guru matematika harus mampu dalam merancang proses pembelajaran di kelas agar menarik peserta didik untuk belajar matematika dengan baik. Stigma matematika sebagai pelajaran yang sulit harus sebisa mungkin dapat dihilangkan terlebih dahulu dari pandangan peserta didik sebelum pembelajaran dimulai. Hal ini diharapkan dapat mendorong semangat belajar peserta didik untuk mendapatkan hasil belajar matematika yang baik sehingga penerapan dan pentingnya matematika pun dapat bermakna bagi diri peserta didik.

Hasil wawancara yang peneliti lakukan dengan salah satu guru matematika di SMP Negeri 17 Kota Bengkulu didapati bahwa pada SMP Negeri 17 Kota Bengkulu telah menggunakan kurikulum 2013, teknik pembelajaran matematika yang biasanya dilakukan menggunakan pembelajaran ekspositori dan masih ada sebagian peserta didik yang tidak menyukai pelajaran matematika. Peserta didik yang lebih dulu menganggap bahwa matematika sulit untuk dipahami memberikan stigma negatif matematika di dalam dirinya, yang akhirnya menutup diri mereka untuk matematika. Hal ini dibuktikan dengan masih adanya peserta didik yang tidak mencapai Kriteria Ketuntasan Minimal (KKM) pada salah satu hasil tes evaluasi belajar yang dilakukan oleh guru tersebut untuk salah satu kelas yang diajar, dari 26 peserta didik ada 13 peserta didik atau sekitar $50 \%$ yang belum mencapai KKM. Anggapan peserta didik yang menyatakan bahwa matematika ini sulit dipahami yang berujung pada sifat malas peserta didik dalam mempelajarinya disadari atau tidak pada akhirnya berujung pada hasil belajar peserta didik.

Seorang guru hendaknya mengusahakan melaksanakan pembelajaran di kelas, mengatur jalannya pembelajaran dengan sebaik mungkin. Guru terkadang harus menggunakan modelmodel pembelajaran tertentu guna mensiasati agar tercapainya hasil pembelajaran yang diinginkan. Salah satu model pembelajaran yang dapat digunakan yaitu model Think-PairShare. Thobroni (2016:245) menyatakan model pembelajaran Think Pair Share sebagai alternatif model pembelajaran yang bisa diterapkan selain model tradisional yang biasa diterapkan dikelas. Dengan model pembelajaran ini diharapkan peserta didik dapat mengembangkan kemampuan berpikirnya sekaligus bertransfer pikiran dengan peserta didik lain sehingga peserta didik dapat mengoptimalkan kegiatan belajar. Teroptimalnya pembelajaran seorang peserta didik inilah yang akan mengakibatkan hasil belajar yang didapat peserta didik menjadi meningkat. 
Model pembelajaran Think-Pair-Share adalah salah satu model pembelajaran pada metode pembelajaran struktural. Model ini pertama kali di kembangkan oleh Frank Lyman dan koleganya pada tahun 1981 di Universitas Maryland. Slavin (2005:4) menyatakan bahwa pembelajaran kooperatif merujuk pada berbagai macam metode pengajaran yang menempatkan peserta didik bekerja dalam kelompokkelompok kecil untuk saling membantu satu sama lain dalam mempelajari materi pembelajaran. Sedangkan untuk metode struktural ini dikembangkan oleh Spencer Kagan dan kawan-kawannya. Menurut Kagan (dalam Thobroni 2016:244) metode struktural menekankan pada struktur-struktur khusus yang dirancang untuk memengaruhi pola interaksi peserta didik guna meningkatkan penguasaan isi akademik.

Model pembelajaran Think-Pair-Share diharapkan dapat membantu para guru untuk mengatur variasi pola diskusi pembelajaran di kelas. Menurut Trianto (2011:81), Think-PairShare atau berpikir-berpasangan-berbagi merupakan jenis pembelajaran untuk mempengaruhi pola interaksi peserta didik. Tahapan yang ada pada model pembelajaran Think-Pair-Share memungkinkan untuk peserta didik memiliki banyak waktu untuk berpikir dan saling berhubungan antar peserta didik. Dengan tahapan pembelajarannya dan tanpa melupakan skala kecil anggota kelompok yang dibentuk yakni berpasangan, dapat mencegah adanya anggota pasangan yang tidak berpikir seperti halnya pada pembelajaran kelompok dengan anggota lebih banyak yang terkadang bila tidak tepat dilakukan akan menyebabkan hanya beberapa peserta didik saja yang berpikir dalam kelompok belajar tersebut.

Ada tiga tahapan utama pada pembelajaran yaitu tahap Thinking, Pairing, dan Sharing seperti yang tertera dalam Majid (2013:191) yakni: tahap Thingking, Pairing, dan Sharing. Pada tahap Thinking, guru mengajukan pertanyaan atau masalah yang berhubungan dengan pelajaran, kemudian peserta didik diminta untuk memikirkan pertanyaan atau masalah tersebut secara mandiri untuk beberapa saat. Pada tahap Pairing, guru meminta peserta didik agar berpasangan dengan peserta didik yang lain untuk mendiskusikan apa yang telah dipikirkannya pada tahap pertama. Interaksi pada tahap ini diharapkan dapat berbagi jawaban jika telah diajukan sautu pertanyaan, atau berbagi ide jika suatu persoalan khusus telah diidentifikasi. Biasanya guru memberikan waktu 4-5 menit untuk berpasangan. Sedangkan pada tahap Share, guru meminta kepada pasangan untuk berbagi dengan seluruh kelas tentang apa yang telah mereka bicarakan. Hal ini cukup efektif jika dilakukan dengan cara bergiliran antara pasangan demi pasangan, dan dilanjutkan sampai sekitar seperempat pasangan telah mendapatkan kesempatan untuk melaporkan.

Pembelajaran dengan model pembelajaran Think-Pair-Share mengajarkan peserta didik bagaimana untuk berpendapat dan menghargai pendapat orang lain dengan skala kelompok belajar terkecil yakni berpasangan. Hal ini diharapkan dapat meningkatkan aktivitas seluruh siswa dalam pembelajaran. Peningkatan aktivitas ini nantinya diharapkan dapat berujung pada peningkatan hasil belajar siswa. Hal ini sejalan dengan Kusuma, dkk (2012) yang menyimpulkan bahwa model pembelajaran Think Pair Share dapat meningkatkan aktivitas belajar matematika siswa.

Aktivitas belajar siswa dalam susatu pembelajaran selanjutnya menggiring perilaku siswa dalam memahami matematika. Ketika siswa tersebut terlibat aktif dalam pembelajaran, sedikit banyak secara siswa tersebut dapat memahami apa yang ditemukannya dalam kegiatan pembelajaran tersebut. Zulkarnain dan Djamilah (2015) menyimpulkan bahwa model pembelajaran Think Pair Share dapat meningkatkan kemampuan pemahaman matematis siswa di sekolah menenagh pertama.

Berdasarkan penelitian yang dilakukan Verowita, dkk (2012) menyimpulkan bahwa model pembelajaran Think Pair Share 
memengaruhi pemahaman konsep matematika siswa sehingga dapat memengaruhi hasil belajar siswa. Penelitian yang dilakukan oleh Putri, dkk (2014) juga menyimpulkan bahwa

\begin{tabular}{|ccc|}
\hline $\mathbf{Y}$ & $\begin{array}{c}\mathbf{X} \\
\text { Model } \\
\text { Pretes } \\
\text { pembelajaran } \\
T P S\end{array}$ & $\begin{array}{c}\mathbf{Y} \\
\text { Postes }\end{array}$ \\
\hline $\mathbf{Y}$ & $\begin{array}{c}\text { Variabel } \\
\text { kontrol } \\
\text { (Ekspositori) }\end{array}$ & $\begin{array}{c}\mathbf{Y} \\
\text { Postes }\end{array}$ \\
\hline
\end{tabular}

pada pembelajaran matematika kelas dengan model pembelajaran Think Pair Share lebih peningkatan aktivitas dan hasil belajar dibandingkan dengan kelas kontrol yang menggunakan pembelajaran ekspositori. Selain itu, pada peneltian Syahri (2017) menyimpulkan bahwa terdapat pengaruh yang signifikan dari model pembelajaran Think Pair Share terhadap hasil belajar matematika siswa.

Berdasarkan uraian tersebut dapat disimpulkan bahwa suatu model pembelajaran dapat memengaruhi hasil belajar matematika siswa, begitupun dengan model pembelajaran Think Pair Share. Namun hal ini masih perlu dibuktikan secara ilmiah. Hal inilah yang mendukung peneliti untuk melakukan penelitian dengan judul "Pengaruh Model Pembelajaran Think Pair Share terhadap Hasil Belajar Matematika Siswa Kelas VIII SMPN 17 Kota Bengkulu".

\section{METODE}

Jenis penelitian yang akan dilaksanakan pada penelitian ini adalah penelitian eksperimen semu. Pada penelitian ini ditetapkan dua kelas sebagai sampel, satu kelas eksperimen yang diberikan perlakuan dengan model pembelajaran Think Pair Share dan satu kelas kontrol tanpa diberikan perlakuan dengan model pembelajaran Think Pair Share. Sugiyono (2008:114) menyatakan bahwa penelitian eksperimen semu memiliki kelas kontrol tetapi hal ini tidak berfungsi untuk mengontrol sepenuhnya variabel-variabel luar yang mempengaruhi pelaksanaan eksperimen, hanya beberapa variabel saja yang dikontrol sesuai dengan eksperimen yang dilakukan. Ada dua variabel yang dilibatkan pada penelitian ini yaitu satu variabel bebas adalah model pembelajaran Think Pair Share (X) dan satu variabel terikat adalah hasil belajar siswa (Y).

Desain penelitian ini adalah The Nonequivalent Pretest-Posttest Control Design, yakni sebagai berikut:

\section{Gambar 3.1 Desain Penelitian}

Populasi yang diambil pada penelitian ini adalah siswa Kelas VIII SMPN 17 Kota Bengkulu. Pada penelitian ini sampel yang diambil merupakan bagian dari populasi Kelas VIII SMPN 17 Kota Bengkulu. Ada dua sampel yang diambil yakni Kelas VIII.D dan VIII.E, Kelas VIII.D sebagai kelas eksperimen dan Kelas VIII.E sebagai kelas kontrol. Pemilihan sampel dilakukan dengan teknik Purposive Sampling, teknik pemilihan sampel dari populasi yang dilakukan dengan pertimbangan tertentu yakni berdasarkan nilai rata-rata siswa yang hampir sama.

Teknik pengumpulan data dilakukan dengan tes. Ada dua tes yang dilakukan, yakni pretes dan postes. Pretes dilakukan sebelum model pembelajaran diterapkan oleh peneliti sedangkan postes diberikan setelah model pembelajaran telah diterapkan peneliti sebanyak 6 kali pada kedua kelas sampel. Soal pretes terdiri dari 5 buah soal uraian dengan materi sebelum materi pembelajaran pada penelitian (kubus dan balok), yakni materi lingkaran. Soal postes terdiri dari 8 soal mengenai materi kubus dan balok. Untuk soal pretes hanya dilakukan validitas logis oleh dua orang validator ahli, seedangkan untuk soal postes dilakukan validitas logis dan empiris. Validitas empiris dilakukan dengan menguji valdiitas, reliabilitas, daya pembeda, dan taraf kesukaran soal. Setelah diujicobakan, pada soal postes ada 2 soal yang dibuang sehingga hanya ada 6 soal yang digunakan untuk soal postes.

Data pada penelitian ini dikelompokkan menjadi tiga bagian, yakni: pretes-pretes (hasil 
pretes kedua kelas sampel), pretes-postes (hasil pretes dan postes masing-masing kelas sampel), dan postes-postes (hasil postes-postes kedua kelas sampel). Analisis data pada penelitian ini dilakukan dengan bantuan program SPSS SPSS.23.0 for windows. Analisis data dilakukan dengan uji-t. Sebelum dilakukan uji-t, data harus diuji prasyarat terlebih dahulu yakni dengan uji normalitas dan uji homogenitas agar data tersebut dapat diolah dengan uji-t. Rumus uji-t adalah sebagai berikut :

$$
t=\frac{\overline{x_{1}}-\overline{x_{2}}}{\sqrt{\frac{\left(n_{1}-1\right) s_{1}^{2}+\left(n_{2}-1\right) s_{2}^{2}}{n_{1}+n_{2}-2}\left(\frac{s_{1}{ }^{2}}{n_{1}}+\frac{s_{2}^{2}}{n_{2}}\right)}}
$$

Keterangan :

(Sumber : Sugiyono, 2017:138)

$\overline{x_{1}}$ : Nilai rata-rata hasil belajar peserta didik kelas eksperimen

$\overline{x_{2}} \quad$ : Nilai rata-rata hasil belajar peserta didik kelas kontrol

$n_{1} \quad$ : Jumlah siswa kelas eksperimen

$n_{2} \quad$ : Jumlah siswa kelas kontrol

$s_{1}{ }^{2}$ : Varians kelas eksperimen

$s_{2}{ }^{2}$ : Varians kelas kontrol

Uji-t dilakukan untuk melihat ada tidaknya perbedaan hasil belajar antara kelas kontrol dan eksperimen. Untuk data pretes-postes, uji-t yang digunakan adalah uji-t sampel berpasangan sedangkan untuk data postespostes uji-t yang dilakukan adalah uji-t sampel independen. Pada output SPSS, ${ }^{H_{0}}$ ditolak apabila nilai sig.(2-tailed) < taraf signifikan ( $\alpha=0,05$ ) yang mengindikasikan bahwa terdapat perbedaan 2 kelompok nilai yang diinputkan pada SPSS yakni hasil belajar siswa.

Pada data pretes-postes dilakukan pula uji $\mathrm{N}-$ Gain. N-Gain pertama kali digunakan oleh Hake (1999) pada penelitiannya. N-Gain digunakan untuk melihat angka kenaikan hasil belajar siswa. Pada penelitian ini N-Gain digunakan untuk melihat kenaikan hasil belajar sebelum dan sesudah model pembelajaran diterapkan, yakni pada data pretes dan postes kelas sampel. Rumus untuk menghitung NGain adalah sebagai berikut :

$$
N-\text { gain }=\frac{S_{\text {post }}-S_{\text {pre }}}{S_{\text {maks }}-S_{\text {pre }}}
$$

(Sumber : Hake, 1999:1)

Keterangan :

$S_{\text {post }}:$ Skor tes akhir

$S_{\text {maks }}:$ Skor maksimum

$S_{\text {pre }} \quad$ : Skor tes awal

Hake (1999:1) mengkategorikan perolehan skor atas tiga kategori, yakni:

$$
\begin{array}{ll}
\text { Tinggi } & : g \geq 0,7 \\
\text { Sedang } & : 0,3 \leq g<0,7 \\
\text { Rendah } & : g<0,3
\end{array}
$$

Pada rumus tersebut jika skor pretes 100, maka akan muncul angka tak terdefinisi. Weber (2009) menyatakan bahwa jika angka pada hasil tes awal telah mendekati nilai maksimum misal 100, maka hanya akan menghasilkan angka infinity atau negative infinity, sehingga angka tidak perlu dilakukan perhitungan $\mathrm{N}$ Gain untuk nilai pretes yang telah 100 .

\section{HASIL DAN PEMBAHASAN}

Data pretes dan postes yang telah didapat kemudian direkapitulasi. Untuk data pretes total skor benar adalah 100 sehingga skor didapat adalah nilai siswa. Namun, untuk soal postes dikarenakan total keseluruhan skor tidak 100 maka perlu dilakukan perhitungan nilai terlebih dahulu setelah skor siswa didapat.

Tabel 4.12 Hasil Pretes dan Postes

\begin{tabular}{|c|c|c|c|c|}
\hline & $\begin{array}{c}\text { Jenis } \\
\text { data }\end{array}$ & $\begin{array}{c}\text { Nilai } \\
\text { tertinggi }\end{array}$ & $\begin{array}{c}\text { Nilai } \\
\text { terendah }\end{array}$ & $\begin{array}{c}\text { Rata- } \\
\text { rata }\end{array}$ \\
\hline $\begin{array}{c}\text { Kelas } \\
\text { Eksperimen }\end{array}$ & Pretes & 21 & 78 & 46,08 \\
\cline { 2 - 5 } & Postes & 40 & 100 & 71,37 \\
\hline Kelas & Pretes & 20 & 75 & 41,04 \\
\cline { 2 - 5 } Kontrol & Postes & 28,57 & 97,14 & 61,19 \\
\hline
\end{tabular}

didapatkan kemudian diloah untuk diuji normalitas, homogenitas, uji-t, dihitung nilai $\mathrm{N}$ Gain-nya. Hasil uji normalitas data pada penelitian ini ditunjukkan pada tabel berikut :

Tabel 4.13 Hasil Uji Normalitas

\begin{tabular}{|c|c|c|c|c|}
\hline $\begin{array}{c}\text { Nama } \\
\text { Tes }\end{array}$ & Kelas & Sig. & $\begin{array}{c}\text { Sig. } \\
\boldsymbol{\alpha}\end{array}$ & Ket. \\
\hline Pretes & Eksperimen & 0,175 & \multirow{2}{*}{0,05} & Normal \\
\cline { 1 - 3 } Pretes & Kontrol & 0,413 & & Normal \\
\hline
\end{tabular}




\begin{tabular}{|c|c|c|c|c|}
\hline $\begin{array}{c}\text { Nama } \\
\text { Tes }\end{array}$ & Kelas & Sig. & $\begin{array}{c}\text { Sig. } \\
\boldsymbol{\alpha}\end{array}$ & Ket. \\
\hline Postes & Eksperimen & 0,380 & & Normal \\
\hline Postes & Kontrol & 0,424 & & Normal \\
\hline
\end{tabular}

Hasil uji homogenitas data ditunjukka pada tabel berikut :

Tabel 4.14 Hasil Uji Homogenitas

\begin{tabular}{|c|c|c|c|c|}
\hline Data 1 & Data 2 & Sig. & $\begin{array}{c}\text { Sig. } \\
\alpha\end{array}$ & Ket. \\
\hline Pretes Kelas & Pretes & 0,45 & & Homogen \\
Eksperimen & Kelas & 6 & & \\
& Kontrol & & & \\
\cline { 1 - 2 } Postes & Postes & 0,57 & & Homogen \\
Kelas & Kelas & 6 & & \\
Eksperimen & Kontrol & & \multirow{2}{*}{0,05} & \\
\hline Pretes Kelas & Postes & 0,87 & & Homogen \\
Eksperimen & Kelas & 7 & & \\
& Eksperimen & & & \\
\cline { 1 - 2 } Pretes Kelas & Postes & 0,15 & & Homogen \\
Kontrol & Kelas & 2 & & \\
& Kontrol & & & \\
\hline
\end{tabular}

Setelah data diujiprasyarat, kemudian dilihat apadakh data tersebut dapat dilakukan uji hipotesis dengan uji-t atau tidak. Syarat dilakukannya uji-t adalah data harus berdistribusi normal dan homogen. Tabel 4.13 dan Tabel 4.14 menunjukkan bahwa data pretes dan postes kedua kelas sampel adalah normal dan pasangan-pasangan data yang akan diuji juga homogen.

Uji hipotesis dilakukan dengan uji-t untuk hasil postes kedua kelas sampel didapat hasil angka sig.(2-tailed) $=0,047<$ taraf signifikan $(\alpha=0,05) \quad$ dan $\quad t_{\text {hitung }}=2,041>t_{\text {tabel }}=$ 2,010635 yang menunjukkan bahwa terdapat perbedaan antara hasil belajar matematika antara siswa dengan pembelajaran Think Pair Share dan ekspositori. Sedangkan pada uji-t sampel berpasangan untuk kelas eksperimen didapat hasil sig.(2-tailed) $=0,000<\operatorname{taraf}$ signifikan $(\alpha=0,05)$ yang menunjukkan bahwa terdapat perbedaan yang signifikan antara hasil belajar siswa sebelum dan sesudah model pembelajaran Think Pair Share diterapkan.

Selain uji-t, hasil perhitungan N-Gain menunjukkan bahwa pada kelas eksperimen dengan pembelajaran Think Pair Share, angka kenaikan nilai yakni 0,47 sedangkan pada kelas kontrol 0,34. Walaupun kedua kelas berada pada N-Gain dengan kategori sedang, namun pada kelas eksperimen dengan model pembelajaran Think Pair Share lebihi tinggi 0,13 dibanding kelas kontrol dengan pembelajaran ekspositori. Grafik N-Gain dapat dilihat pada gambar berikut:

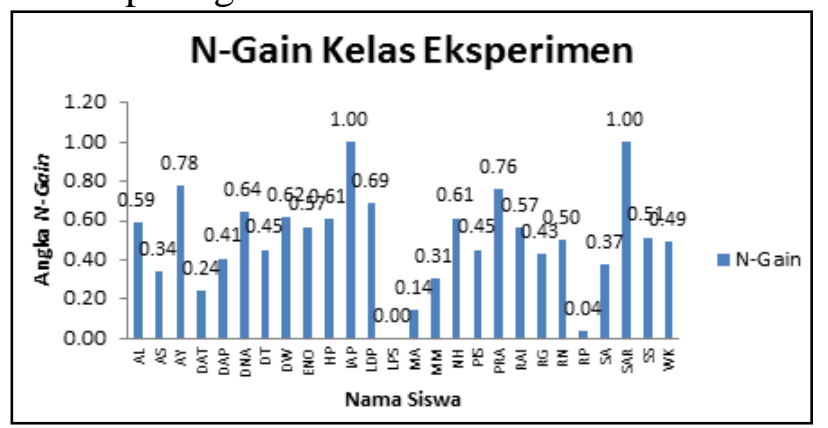

Gambar 4.3 Grafik Nilai N-Gain Kelas Eksperimen

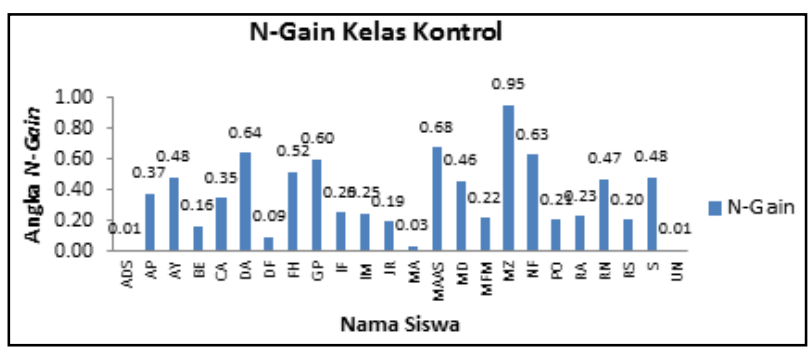

Gambar 4.6 Grafik Nilai N-Gain Kelas Kontrol

Ketika peneliti melaksanakan penelitian, perbedaan pola pembelajaran jelas terasa pada proses pembelajaran di kedua kelas sampel. Model yang diterapakan di salah satu kelas sampel adalah model pembelajaran dari metode struktural yang memang dimaksudkan untuk membuat pola interaksi siswa pada proses pembelajaran sedikit berbeda dengan pembelajaran yang biasanya dilakukan pada kelas sampel tersebut. Hal ini sejalan dengan Kagan (dalam Thobroni 2016:244) yang menyatakan bahwa metode struktural dirancang untuk memengaruhi pola interaksi peserta didik guna meningkatkan penguasaan isi akademik.

Pada penelitian ini, awal proses pembelajaran yakni pendahuluan dilakukan peneliti sebagaimana pendahuluan pada tahap pembelajaran yang biasa dilakukan, yakni dengan mengucapkan salam, berdoa, mengecek 
kehadiran siswa motivasi dan apersepsi untuk pembelajaran yang akan di pelajari, menyiapkan siswa untuk melaksanakan kegiatan inti pembelajaran. Kegiatan inti pembelajaran pada kelas eksperimen dilakukan dengan tahap model pembelajaran Think Pair Share, sedangkan pada kelas kontrol dengan pembelajran ekspositori. Pada kegiatan penutup juga dilakukan sebagaimana kegiatan penutup pada pembelajaran yang biasa dilakukan, yakni siswa dan guru bersama menyimpulkan apa yang telah dipelajari pada pertemuan pembelajaran tersebut, siswa diberitahu materi apa yang akan dipelajari pada pertemuan berikutnya, siswa diberikan motivasi agar terus bersemangat dalam melaksanakan pembelajaran, dan terakhir mengucapkan salam.

Pada kelas eksperimen pembelajaran sudah mulai terpusat kepada siswa. Siswa sudah lebih aktif, mulai berpikir dan berdiskusi dengan kelompoknya. Hal ini sesuai dengan pendapat Kurniasih (2015:58-60) yang menyatakan bahwa model pembelajaran Think-Pair-Share dapat meningkatkan partisipasi peserta didik dalam proses pembelajaran, dengan sendirinya memberikan kesempatan yang banyak kepada peserta didik untuk berpikir, menjawab, dan saling membantu satu sama lain.

Siswa pada kelas ekseperimen yang terdiri dari 26 orang siswa dibagi menjadi 13 kelompok dengan tiap kelompoknya terdiri dari 2 orang siswa. Pola pembelajaran pada kelas eksperimen dimulai dari siswa diberikan kesempatan berpikir secara individu pada tahap Think, kemudian berdiskusi dengan kelompok terkecil yakni berpasangan pada tahap Pair, dan barulah apa yang telah mereka dapati dari tahap Think dan Pair mereka bawa ke kelompok yang lebih besar yakni dengan membagikan apa yang telah mereka temukan ke seluruh siswa dalam kelas tersebut yang disebut dengan tahap Share. Sedangkan pada kelas kontrol pembelajaran masih banyak terpusat kepada guru, siswa diberikan materi secara langsung oleh guru.
Pada kelas eksperimen siswa diberikan LKPD yang telah dirancang sesuai dengan model pembelajaran Think Pair Share (TPS) sedangkan pada kelas kontrol tidak diberikan LKPD. LKPD ternyata juga membantu siswa untuk lebih semangat belajar, dengan adanya gambar-gambar dan langkah-langkah pada LKPD membuat siswa lebih tertarik untuk belajar. Tidak hanya LKPD beberapa kali, peneliti juga menghadirkan benda konkret (kubus dan balok) guna mendukung proses berpikir siswa.

Pada tahap Think untuk pembelajaran dengan model Think Pair Share, setiap siswa diberikan LKPD. Siswa diminta untuk mengerjakan apa yang ada pada tahap Think pada LKPD tersebut. Kemudian hasil dari apa yang mereka temukan pada tahap Think akan mereka diskusikan bersama pasangannya dalam kelompok untuk tahap Pair. Setelah siswa diberikan waktu sekitar 3-5 menit untuk berdiskusi kemudian dilakukanlah tahap Share yakni siswa membagikan kepada seluruh kelas apa yang telah didapat dari hasil diskusi kelompok yang telah dilakukan.

Pada pertemuan pertama, kedua kelas sampel melaksanakan pembelajaran untuk materi jaring-jaring kubus. Pada awal pembelajaran kelas eksperimen, siswa diberikan motivasi dan apersepsi untuk materi jaring-jaring kubus. Kemudian siswa diberikan contoh bangun ruang kubus, ditampilkan sebuah kubus yang terbuat dari karton. Setelah apersepsi dan motivasi, siswa diberikan LKPD untuk kemudian mengerjakan tahap Think yang ada pada LKPD tersebut. Siswa diminta memerhatikan dan memelajari tabel contoh jaring-jaring kubus dan bukan jaring-jaring kubus. Setelah memahami tabel, siswa diminta untuk menggambarkan jaring-jaring kubus dengan bentuk yang berbeda dengan bentuk jaring-jaring kubus yang ada pada tabel. Dalam menggambar jaring-jaring kubus, siswa melakukan usaha yang beragam. Ada siswa yang memotong kertas kecil untuk diutak-atik apakah dapat membentuk sebuah kubus. Ada juga siswa yang hanya memperhatikan tabel 
langsung dapat memikirkan bentuk jaringjaring yang lain. Selain itu, ada juga siswa yang mencoba-coba dengan menggambar pada kertas lain terlebih dahulu untuk menemukan gambar jaring-jaring kubus yang berbeda. Pada tahap Think, siswa juga diminta untuk menuliskan pengertian jaring-jaring kubus menurut pendapatnya sendiri yang kemudian didiskusikan bersama pasangannya dalam kelompok pada tahap Pair. Setelah berdiskusi dengan pasangannya, kemudian siswa menyampaikan hasil diskusi kelompoknya kepada siswa-siswa lain di kelas tersebut, yakni pada tahap Share. Pada gambar berikut terlihat seorang siswa PIS sedang maju kedepan untuk memperjelas apa yang ia dan pasangannya bagikan pada tahap Share untuk membagikan apa yang ia dan kelompoknya temukan kepada seluruh siswa dalam kelas tersebut.

Pada pertemuan keempat yakni untuk jaring-jaring balok peneliti menyiapkan satu balok kecil yang terbuat dari karton untuk masing-masing siswa untuk memudahkan siswa pada tahap Think. Pada tahap Think untuk pertemuan keempat ini, ketika siswa diminta untuk menggambar jaring-jaring balok siswa langsung membongkar balok yang telah diberikan kepada setiap siswa. Ternyata dengan memberikan balok untuk setiap siswa membuat siswa lebih aktif dan semangat untuk menemukan bentuk jaring-jaring balok dibandingkan dengan pertemuan pertama.

Pada pertemuan kedua, ketiga, keempat, kelima, dan keenam kelas eksperimen, langkah pembelajaran hampir sama dengan pertemuan pertama. Pada pertemuan kedua materi pembelajaran yakni luas permukaan kubus, pada pertemuan pembelajaran ini siswa diminta untuk menemukan rumus atau cara untuk menghitung luas permukaan suatu kubus. Siswa dibimbing menggunakan LKPD untuk mencari rumus tersebut dengan pendekatan terhadap jaring-jaring kubus yang telah dipelajari pada pertemuan sebelumnya. Begitupun halnya ketika pada pertemuan kelima untuk materi luas permukaan balok, juga dihubungkan dengan materi sebelumnya yakni jaring-jaring balok.

Pada pertemua ketiga kelas eksperimen, materi pembelajaran yakni volume kubus. Selain menggambarkan ilustrasi/gambar pada LKPD guna menemukan rumus volume kubus, peneliti juga menyiapkan model sebuah kubus besar dengan kubus satuan sebagai isi. Hal ini untuk membantu siswa dalam membayangkan gambar yang ada pada LKPD. Pada pertemuan keenam pun, peneliti melakukan hal yang sama untuk membantu siswa berpikir untuk menemukan rumus volume balok. Hanya kubus besar tersebut diganti dengan balok yang diisi dengan kubus satuan.

Materi yang dipelajari kedua kelas sampel adalah sama, yakni kubus dan balok. Hanya saja, model pembelajaran untuk siswa memperlajari materi tersebut berbeda pada kedua kelas sampel. Pada kelas kontrol untuk pertemuan pertama, tanpa berpikir untuk menemukan sendiri apa yang dimaksud dengan jaring-jaring kubus, siswa langsung diberikan pengertian mengenai jaring-jaring kubus. Pada pertemuan kedua dan ketiga, rumus untuk luas permukaan dan volume kubus langsung disampaikan kepada siswa. Begitupun halnya untuk pembelajaran pada materi balok, yakni jaring-jaring, luas permukaan, dan volume balok.

Pada kelas kontrol, kegiatan pembelajaran terasa lebih 'hening', hal ini dikarenakan siswa langsung memperhatikan apa yang disampaikan oleh peneliti, memang tanya jawab tetap berlangsung namun tidak seaktif pada kelas eksperimen yang diberikan pembelajaran Think Pair Share. Pada kelas kontrol, karena materi telah secara langsung diberikan kebanyakan siswa tidak penasaran lagi dengan bagaimana dan mengapa materi tersebut seperti itu adanya. Berbeda dengan kelas eksperimen yang memang dikarenakan proses pembelajaran pada awalnya mempersilahkan mereka untuk berpikir terlebih dahulu membuat mereka lebih mendalami apa dan bagaimana suatu materi yang mereka temui pada pembelajaran tersebut. Siswa juga 
diarahkan untuk aktif berdiskusi dan menyampaikan penadapat pada tahap Pair dan Share.

Meskipun secara umum siswa pada kelas eksperimen pola pembelajaran Think Pair Share dapat terlaksana sebagaimana mestinya, namun bukan berarti semua siswa pada kelas eksperimen menyukai pola pembelajaran dengan Think Pair Share dan tidak ada masalah yang terjadi. Ada siswa dari mereka lebih menyukai pembelajaran seperti biasanya yakni dengan ekspositori. Peneliti mendapati siswa yang malas untuk berpikir pada tahap Think dan hanya menunggu tahap Pair untuk langsung menyalin apa yang telah didapat temannya pada tahap Think. Peneliti juga mendapati ada siswa yang pada tahap Think namun langsung melakukan Pair-ing. Maksudnya disini kedua siswa tersebut melakukan tahap Think dan Pair secara bersamaan. Mereka mengisi apa yang ada pada tahap Think sekaligus mendiskusikan LKPD secara bersama-sama dengan pasangannya.

Setelah peneliti melakukan pendekatan kepada siswa tersebut, ternyata siswa tersebut mengalami kesulitan pada tahap Think. Siswa tersebut mengalami kesulitan ketika harus berpikir sendiri menangani permasalahan yang diberikan kepadanya. Sehingga pada pertemuan berikutnya, siswa-siswa tersebut harus benarbenar didampingi peneliti ketika pada tahap Think. Peneliti hanya membimbing dan mengarahkan siswa tersebut untuk mendapatkan apa yang diinginkan pada tahap Think tanpa menyampaikan secara langsung kepada siswa tersebut apa yang harus ditulis di LKPD pada tahap Think tersebut.

Peneliti juga mendapati beberapa siswa yang memang kesulitan untuk menyampaikan pendapatnya di depan kelas. Hal ini peneliti temui ketika pada tahap Share, ada siswa yang malu dan tidak berani untuk menyampaikan pendapatnya. Setelah peneliti dekati siswa tersebut, siswa tersebut mengatakan bahwa memang ia tidak terbiasa untuk berbicara di depan kelas. Siswa tersebut takut jika yang ia sampaikan salah, maka akan ditertawakan ataupun diejek oleh siswa lain. Perasaan tidak percaya diri, takut, dan malu inilah yang menyebabkan siswa tersebut enggan mengemukakan pendapatnya di depan kelas. Sehingga, siswa tersebut harus diberi motivasi dan semangat dorongan terus untuk berani berbicara di depan kelas, sehingga pada pertemuan selanjutnya siswa tersebut pun telah lebih berani untuk berbicara di depan kelas.

Demikian, bukan berarti masalah tidak terjadi juga pada kelas kontrol. Pada kelas kontrol, banyak siswa yang merasa mengantuk dan bosan ketika harus memperhatikan penjelasan guru setelah beberapa waktu kegiatan pembelajaran berjalan. Apalagi jika siswa menemui kesulitan pada proses untuk memahami suatu materi, siswa tersebut cenderung mudah menyerah. Dalam artian, ketika tidak mengerti mereka akan berhenti memeperhatikan, bosan, dan mengantuk.

Pola interaksi pembelajaran yang berbeda menyebabkan antusiasme dan keaftifan siswa pada proses pembelajaran di kedua kelas sampel pun berbeda. Perbedaan pada proses dan aktivitas pembelajaran ini akhirnya berimbas pada rata-rata hasil belajar siswa yang akhirnya mendukung pernyataan hasil uji hipotesis bahwa terdapat perbedaan antara ratarata hasil belajar matematika pada kedua kelas sampel.

\section{PENUTUP \\ Simpulan}

Berdasarkan hasil penelitian yang telah peneliti lakukan disimpulkan bahwa terdapat pengaruh model pembelajaran Think Pair Share terhadap hasil belajar siswa Kelas VIII SMPN 17 Kota Bengkulu. Hal ini didukung oleh hasil uji statistik uji-t untuk pretes-postes pada masing-masing kelas sampel, uji statistik uji-t untuk hasil postes kedua kelas sampel, dan hasil perhitungan nilai peningkatan hasil belajar masing-masing kelas sampe. Pada uji-t paired untuk hasil pretes dan postes kelas eksperimen didapat angka sig.(2-tailed) $=0,000<$ taraf signifikan $(\alpha=0,05)$ yang menunjukkan bahwa terdapat perbedaan yang signifikan 
antara hasil belajar siswa sebelum dan sesudah model pembelajaran Think Pair Share diterapkan. Sedangkan pada uji-t independen hasil postes kelas sampel dengan taraf signifikan $(\alpha=0,05)$ didapat sig.(2-tailed) $=$ $0,047<$ taraf signifikan $(\alpha=0,05)$ dan $t_{\text {hitung }}=2,041>t_{\text {tabel }}=2,010635 \quad$ yang menunjukkan bahwa terdapat perbedaan antara hasil belajar matematika antara siswa dengan pembelajaran Think Pair Share dan ekspositori. Pada perhitungan nilai $\mathrm{N}$-Gain didapat rata-rata angka N-Gain pada kelas eksperimen yakni 0,47(sedang) dan kelas kontrol 0,34 (sedang), didapati bahwa angka kenaikan hasil belajar pada kelas eksperimen lebih tinggi daripada kelas kontrol. Hasil penelitian menunjukkan bahwa terdapat pengaruh model pembelajaran Think Pair Share terhadap hasil belajar matematika siswa Kelas VIII SMPN 17 Kota Bengkulu.

\section{Saran}

Saran yang dapat peneliti berikan berdasarkan hasil penelitian yang telah dilakukan, yakni:

1. Ketika penerapan model pembelajaran Think Pair Share menggunakan LKPD, siswa harus diberikan LKPD per-individu bukan per-kelompok karena jika diberikan perkelompok akan mempengaruhi ketika proses Think berlangsung.

2. Pada penerapan model pembelajaran Think Pair Share, ketika fase Think perhatikan benar-benar setiap siswa. Bisa saja ada siswa yang memang mengalami kesulitan untuk berpikir sendiri sehingga membutuhkan dorongan lebih untuk memahami suatu masalah.

3. Pada penerapan model pembelajaran Think Pair Share, jumlah kelompok yang terbentuk banyak. Tidak semua kelompok dapat menyampaikan hasil diskusinya pada tahap Share ketika satu pertemuan pembelajaran berlangsung. Dalam 6 kali pertemuan pembelajaran pada penelitian,

\begin{abstract}
hendaknya kelompok yang menyampaikan hasil diskusinya pada tahap Share berbeda-beda pada setiap pertemuannya agar semua siswa dapat ikut aktif dan mampu menyampaikan hasil diskusinya di kelas.
\end{abstract}

\section{DAFTAR PUSTAKA}

Hake, Richard R. 1999. Analyzing Change/Gain Score. Woodland Hills, CA : American Educational Research Association's Division D, Measurement and Research Metodology.

Kurniasih, Imas dan Sani, Berlin.2015. Model Pembelajaran. Yogyakarta : Kata Pena.

Kusuma, dkk. 2012. "Impelementasi Model Pembelajaran Kooperatif Tipe Think Pair Share untuk Meningkatkan Aktivitas Belajar Akuntansi Siswa Kelas XI IPS 1 SMA Negeri 2 Wonosari”. Universitas Negeri Yogyakarta : Jurnal Pendidikan Akuntansi Indonesia, Vol.X., No.2:43-63.

Majid, Abdul. 2013. Strategi Pembelajaran. Bandung : PT Remaja Rosdakarya.

National Research Council. 1989. "A Report to The Nation on The Future of Mathematic Education". Everybody Counts: 27-38.

Putri, Siska Yolanda., Yerizon., \& Nilaswati. 2014. "Pengaruh Penerapan Model Pembelajaran Kooperatif Tipe Think Pair Share terhadap Aktivitas dan Hasil Belajar Matematika Siswa Kelas VIII SMPN 31 Padang”. Universitas Negeri Padang : Jurnal Pendidikan Matematika. Part 2. Vol.3, No.1:41-45.

Slavin. Robert E. 2015. Cooperative Learning: Teori, Riset, dan Praktik. Terjemahan oleh Narulita Yusron. Bandung : Nusa Media.

Sugiyono. 2008. Metode Penelitian Pendidikan (Pendekatan Kuantitatif, Kualitatif, dan $R \& I)$. Bandung : Alfabeta.

Syahri, Putri. 2017. "Pengaruh Model Pembelajaran Kooperatif Tipe TPS terhadap Hasil Belajar Matematika Pokok Bahasan Teorema Pythagoras". Al Khawarizmi : Jurnal Pendidikan dan 
Pembelajaran Matematika. Vol.1, No.1:5159. ISSN 2549-3906.

Thobroni, M. 2016. Belajar \& Pembelajaran : Teori dan Praktik. Yogyakarta : Ar-Russ Media.

Verowita, Winda., Murni, Dewi., \& Mirna. 2012. "Pengaruh Penerapan Model Pembelajaran Kooperatif Tipe TPS terhadap Pemahaman Konsep dalam Pembelajaran Matematika". Universitas Negeri Padang : Jurnal Pendidikan Matematika. Part 3. Vol.1, No.1:48-51.

Weber, Everett. 2009. Buletin of Ecological Society of America : Quantifying Student Learning, How to Analyze Assesment Data. Murray : Murray State University.

Zulkarniain, Iskandar. \& Djamilah, Soraya. 2015. "Penerapan Model Pembelajaran Think Pair Share terhadap Kemampuan Pemahaman Matematis Siswa Sekolah Menengah Pertama". Universitas Lambung Mangskurat : Jurnal Pendidikan Matematika, Vol.3., No.1:105-117. 